\author{
Markova T. \\ Ph.D., Assistant \\ Department of Accounting and Auditing \\ Odessa National Academy of Food Technologies \\ Kanatna str., 112, Odessa, Ukraine, 65039 \\ E-mail: markova.tetiana17@gmail.com
}

\title{
ALTERNATIVE ENERGY IN THE SYSTEM OF ECONOMIC ECOLOGICAL SAFETY OF THE STATE
}

The article deals with economic ecological problems of energy supply of Ukraine, prospects and advantages of using alternative technologies of heat supply on the base of technologies use of environment energy.

Key words: energy of environment, economic environmental problems, alternative energy saving technologies, alternative renewable energy.

This work is licensed under a Creative Commons Attribution 4.0 International License http://creativecommons.org/licenses/by/4.0/

Statement of the problem and its connection with important scientific and practical tasks. The limited resources for energy supply from traditional sources, the constant rise in fuel and energy resources in the arena of the world market, the need to reduce the amount of pollutants into the environment, the desire to have access to cheap energy sources make the world community increase the share balance of the use of alternative energy from renewable energy sources in energy. In order to overcome acute energetic, economic environmental, social and political tension in the state, Ukraine needs a transition to alternative energy. According to the authors [1], the main forms of renewable energy development should be: projects that will be implemented by state and private enterprises or in the form of private-public partnerships. One should be aware of the fact that the world today has entered an era of developed innovative processes - equipment and technical systems are based on high technologies using the latest achievements of fundamental and applied research. Ukraine needs to implement transition from energy-saving to innovative technology. The innovative structure of the technological renovation of the heat supply system of settlements of Ukraine should be based on scientific achievements, logistical, financial, personnel resources. The development of the modern Ukrainian economy depends directly on the growth rates of production and consumption of energy from traditional and non-traditional renewable energy sources. Ukraine belongs to the countries that are only partially equipped with their own energy resources. The overall level of import of fuel and energy resources in the total supply of primary energy is $35 \%$ (2015) which increases the risks of energy danger.

The main factor that exacerbates changes in the energy sector of the country is sharp increase, especially in 2009-2014, of gas and oil prices, coal imports and periodic imports of electricity [2], as well as the international community's concern about the rapid pace of climate change. In this regard the problem of introduction of new technologies, in particular environmentally safe, capable of replacing inefficient gas boilers, the majority of CHP plants, replacing natural gas with other fuels and increasing the share of alternative, nonconventional energy which is only $3 \%$ today in the heat energy balance of the Ukrainian state, has become more acute than ever before. The global shortage of fossil energy resources in the world leads to increase in the importance of the effective use of alternative, nontraditional energy sources. These resources include: solar radiation, wind energy, small hydro energy, thermal energy of the environment, the energy of sea waves, thermal waters, as well as thermal discharges of industry, which, incidentally, are quite promising for efficient use in the territory of Ukraine [3].

Therefore, the short-term forecast shows that in Ukraine there should be radical changes in the structure of heat supply sources in the next decade.

The analysis of the latest publications on the problem. As for the outlined issue, the questions are under consideration both on the scientific and on the state levels. Alternative fuel energy to the organic types and perspective methods of its use were the subject of research of such scientists, as O.M. Hromova, I.M. Sotnyk, I.K. Bystriakov, A. A. Dolinskyi, O.M. Sukhodolia, S.V. Yermilov, V.V. Stadnyk, D.K. Turchenko, O.H. Burdo, A.V. Prahkovnyk, A.I. Solovei, V.V. Prokopenko, A.I. Shevtsova, M.H.Zemlianyi, A. Z. Doroshkevych, V.V. Verbytskyi, T.V. Riauzava, O.V.Melnychenko and many others, however today there are many open question in relation to introduction of energykeeping technologies in Ukraine on the base of the use of environment energy, namely: ways of financing, nonfulfillment of the government programs in relation to the 
increase of part of renewed energy in the structure of fuel and energy complex, absence of concrete levers of influence from the state on producers and consumers of unconventional energy.

Forming of the aims of the research. The purpose of the work is to analyze the state of thermal energy release by generating sources, investigate the role and prospects of using energy-saving technologies with the use of energy sources that ensure the economic ecological efficiency of the heating process and contribute to the achievement of the energy and environmental (prevention of climate change) security of Ukraine.

Giving an account of the main results and their substantiation. Issues of energy security of the state cover the most important spheres of life: economic, political, social. The strategy of guaranteeing the ecological safety of Ukraine's social and economic development ultimately determines the economic independence and sovereignty of Ukraine at the present stage. It consists of the transition from the implementation of individual or even complex measures on resource and nature conservation, implementation of the ecological and economic concept of comprehensive rationalization of social production and ensuring its sustainable ecological and economic, energy functioning.

It should be noted that the largest consumers of heat energy in Ukraine are such sectors of the economy as industry, housing and communal services and the social sphere and agriculture. During the years of its independence Ukraine has reduced the share of heat consumption by the main sectors of the economy in the heat and energy balance. The consumption of heat in the industrial sector, housing and communal services and social and agricultural sectors in 1990 amounted to 388 million Gcal, and 20 years later the heat consumption in similar sectors of the economy amounted to only 232 million Gcal or $40.2 \%$ [4]. Such sharp decline is due mainly to the decrease in output in the industrial sector, especially large financial and economic groups of enterprises that eventually left the business arena.

Larger proportion of thermal energy in Ukraine is generated by such sources as power stations, boiler installations, electric boilers, heat-utilizing installations for industrial needs and heating purposes. Analysis of the structure of heat production by these systems for the period 2006-2016 indicates the relative stability of heat release (Table 1). The largest share of the production of heat consumed is generated at boiler houses - almost $63 \%$. At the expense of power stations, $28-33 \%$ of heat is generated. That is, more than $90 \%$ of the thermal energy is generated by power stations and boiler installations. The heat generated by utilization units based on secondary energy resources (SER) takes only $5-7 \%$ in the overall balance.

Table 1

Release of thermal energy by generating sources*

\begin{tabular}{|c|c|c|c|}
\hline \multirow{2}{*}{ Indexes } & \multicolumn{3}{|c|}{ Years } \\
\hline & 2006 & 2010 & 2016 \\
\hline \multirow{2}{*}{$\begin{array}{lr}\text { Total, } & \text { th. Gcal } \\
\text { including: } & \end{array}$} & 181663 & 152006 & 98956 \\
\hline & 100,0 & 100,0 & 100,00 \\
\hline \multirow{2}{*}{$\begin{array}{lr}\text { Power stations, } & \text { th. Gcal } \\
\%\end{array}$} & 51130,0 & 43771 & 33092 \\
\hline & 28,14 & 28,8 & 33,5 \\
\hline \multirow{2}{*}{$\begin{array}{lr}\text { Boiler installations, } & \text { th. Gcal } \\
\%\end{array}$} & 115931 & 96567 & 60194 \\
\hline & 63,82 & 63,5 & 60,8 \\
\hline \multirow{2}{*}{$\begin{array}{lr}\text { Electric boilers, } & \text { th. Gcal } \\
\%\end{array}$} & 43,0 & 45 & - \\
\hline & 0,02 & 0,0 & - \\
\hline \multirow{2}{*}{$\begin{array}{lr}\text { Heat-utilizing installations, } & \text { th. Gcal } \\
\%\end{array}$} & 12892,0 & 10518 & 4583 \\
\hline & 7,1 & 7,0 & 4,6 \\
\hline \multirow{2}{*}{$\begin{array}{rr}\text { Other installations, } & \text { th. Gcal } \\
\%\end{array}$} & 1667,0 & 1105 & 1087 \\
\hline & 0,92 & 0,7 & 1,1 \\
\hline
\end{tabular}

*it is calculated by the author from data $[5,6]$

Secondary energy resources are the energy potential of products, by-products and intermediate products produced in technological units (installations) and lost in the unit itself but may be partially or entirely used for power supply [4]. Rational use of SER is one of the largest reserves for reducing fuel consumption and energy consumption of industrial products. SER can be used directly without changing the type of energy carrier (to meet the need for thermal energy and fuel) or with the change in the type of energy through the producing thermal and electric energy, cold or mechanical work in waste disposal plants.

At the same time, according to the experts the level of SER use including not only highly potential but also low and medium SER is only $40 \%$. It should be noted that the technology of heat production with the help of heat pumps involves the possibility of using a large part of unused SER (heat-cooling water, etc.). Heat 
pumps can work as unique installations for the disposal of low and medium potential SER. The urgency of the effective use of SER is related to the need of improving technological processes and reducing the heat loss of high potential [4]. Utilization of SER of low-potential heat also contributes to the protection of the environment from thermal pollution. It is this factor associated with the receipt and use of energy resources in recent decades has a significant impact on the cost of energy production, on the choice of type of power plant and its location.

In 2016 emission of pollutants into the air from stationary sources of pollution, compared to 2015, increased by $7.7 \%$ and amounted to almost $3.1 \mathrm{mln}$ tons. In addition, from the stationary sources of pollution 150.5 million tons of carbon dioxide reached the atmospheric air (by $8.4 \%$ more, compared to 2015) - the main greenhouse gas that affects climate change [5]. Increased consumption of energy from renewable energy sources is an important part of the package of measures required to comply with the Kyoto Protocol to the UN Framework Convention on Climate Change [3].

It should be noted that the use of renewable energy sources is a powerful market with a powerful multiplier effect in education, science and production which requires and absorbs a significant amount of investments [1].

As far as Ukraine is concerned the development of renewable energy is restrained by a number of obstacles among which are the main ones [1]:

- firstly, financial barriers (limited domestic sources of financing of economic entities and their low creditworthiness, unattractiveness of this sector for external investors, high cost of equipment and research);

- secondly, information barriers (lack of information on conditions for implementation and benefits of renewable energy sources, lack of exchange of positive experience in solving local energy supply problems through renewable energy sources);

- thirdly, organizational and institutional barriers (lack of regulatory base in the field of support for the development of renewable energy sources, institutions capable of active implementation projects in the field of using renewable sources of energy).

It should be noted that many scholars and practitioners point out that the transition to alternative technologies in the energy sector will save the state's fuel resources and that the cost of energy produced by alternative sources is already lower than the cost of energy from traditional sources. Prices are decreasing on alternative energy, on the traditional one - they are constantly increasing.

In Ukraine there are all prerequisites for the rapid development of renewable energy, says Bortnyuk $\mathrm{T}$. The main factors of renewable energy development are [8]:

- lack of sufficient volumes of own organic fuel in Ukraine, energy dependence on its import;

- urgent need to update the equipment in the power industry;

- the state policy on integration into the European Union adopted in Ukraine which requires the achievement of the high level of use of renewable energy sources;

- urgent need to significantly improve the ecological situation in Ukraine.

The use of non-traditional and renewable energy at the present stage of the Ukrainian economy's development is inadequate and does not correspond to the European level. However, gradual steps in the legislative and regulatory base of the state have pushed to the further development of alternative energy in Ukraine. Comparison of the current state of affairs in this field in our country and developed countries shows that the declarative legal documents are not backed up by practical steps. For the implementation of the energy strategy, more attention should be paid to the explanatory work among the population. In fact the awareness of personal responsibility for reducing the ecological burden on the planet forms the general public "green" thinking, provokes the emergence of new ideas and progressive views and as a result gives impetus to further progress in the field of alternative energy [9]. According to the authors [10], one of the main factors of the development of Ukrainian energy industry is the definition and study of non-traditional renewable energy sources, the development of alternative types of energy resources and the prospects of their use.

Conclusions and prospects of the further investigations. Moral out-of-date and physical wear of the thermal power park of the fuel and energy complex of Ukraine, high energy dependence, environmental situation, high economic costs of the heating of the society testify to the need for effective steps in the regulatory and legislative base for the development of various types of alternative energy and stable attractive investment conditions for doing business for investors which will lead to the state's economic and environmental security.

\section{References}

1. Kasych , A. O., Lytvynenko, I. O., \& Melnychuk, P. S. (2013). Alternatyvna enerhetyka: svitovyi ta vitchyznianyi dosvid . Naukovi zapysky Natsionalnoho universytetu «Ostrozka akademiia». Ekonomika., 23, 43-47.

2. Khalatov , A. A. (2016). Enerhetyka Ukrainy: suchasnyi stan i naiblyzhchi perspektyvy . Visnyk Natsionalnoi akademii nauk Ukrainy, 6, 53-61.

3. Mahiiovych, \%. (2012). Alternatyvna enerhetyka: problemy ta perspektyvy rozvytku. Ahrarna ekonomika, 1-2, 5th ser., 105-116.

4. Hromova , O. M., Hetman, O. L., \& Markova, T. D. (2013). Teplonasosna enerhetyka v ekolohizatsii palyvno-enerhetychnoho kompleksu Ukrainy: perspektyvy rozvytku ta mekhanizmy upravlinnia. Odesa: IPREED NANU. 
5. Ofitsiinyi sait Derzhavnoi sluzhby statystyky Ukrainy . (n.d.). Retrieved from http://ukrstat.gov.ua/

6. Fryzorenko, A. O. (2017). Statystychnyi biuleten «Postachannia ta vykorystannia enerhii za 2016 rik» . Derzhavna sluzhba statystyky Ukrainy.

7. Prokopenko, \%. M. (2017). Statystychnyi biuleten «Vykydy zabrudniuiuchykh rechovyn ta parnykovykh haziv u atmosferne povitria vid statsionarnykh dzherel zabrudnennia za 2016 rik». Derzhavna sluzhba statystyky Ukrainy.

8. Bortniuk, T. (2013). Vidnovliuvana enerhetyka Ukrainy . Ekonomichnyi analiz., 12(1), 51-54.

9. Haidaienko , I. (2014). Alternatyvna enerhetyka v Ukraini: stan ta perspektyvy rozvytku . Naukovi zapysky z ukrainskoi istorii, 34th ser., 146-151.

10. Los, L. V., \& Terletskyi, M. D. (2013). Perspektyvna alternatyvna enerhetyka. Visnyk Zhytomyrskoho natsionalnoho ahroekolohichnoho universytetu, 1(1), 203-214.

Received 5 August 2017

Approved 19 August 2017

Available in Internet 30.09.2017

\author{
Маркова Т.Д. \\ кандидат экономических наук, старший преподаватель \\ кафредра учета и аудита \\ Одесская национальная академия пищевых технологий \\ ул. Канатная, 112, г. Одеса, Украина, 65039 \\ E-mail: markova.tetiana17@gmail.com

\section{АЛЬТЕРНАТИВНАЯ ЭНЕРГЕТИКА В СИСТЕМЕ ЭКОНОМИКО- ЭКОЛОГИЧЕСКОЙ БЕЗОПАСНОСТИ ГОСУДАРСТВА}

В статье рассматривается экономико-экологические проблемы энергообеспечения Украины, вызванных энергозависимостью государства от импорта топливно-энергетических ресурсов, а также увеличением объема выбросов вредных веществ в окружающую среду. Рассматривается перспективы и преимущества использования альтернативных технологий теплообеспечения на базе технологий использования энергии окружающей среды.

Проанализировано состояние и динамика отпуска тепловой энергии генерирующими источниками за последние годы. Определены основные препятствия и факторы развития возобновляемой энергетики в Украине. Проанализированы статистические данные по объемов выбросов вредных веществ в окружающую среду, и их увеличение на 8,5\% (2016) по сравнению с предыдущим годом свидетельствует о необходимости внедрения действенных реальных шагов по уменьшению выбросов CO2, что и требует меры, необходимые для соблюдения Киотского протокола к Рамочной конвенции ООН о климатических изменениях.

Моральная устарелость и фризическая изношенность теплоэнергетического парка топливноэнергетического комплекса Украины, высокая энергозависимость, экологическая ситуация, высокие экономические затраты теплообеспечения общества свидетельствуют о необходимости действенных шагов в сфере нормативно-законодательной базы развития различных видов альтернативной энергетики и стабильных привлекательно-инвестиционных условий ведения бизнеса для инвесторов, что приведет к экономико-экологической безопасности государства.

Ключевые слова: энергия окружающей среды, экономико-экологические проблемы, альтернативные энергосберегающие технологии, альтернативная возобновляемая энергетика.

\author{
Маркова Т.Д. \\ кандидат економічних наук, старший викладач \\ кафедра обліку та аудиту \\ Одеська національна академія харчових технологій \\ вул. Канатна, 112, м. Одеса, Україна, 65039 \\ E-mail: markova.tetiana17@gmail.com
}

\title{
АЛЬТЕРНАТИВНА ЕНЕРГЕТИКА В СИСТЕМІ ЕКОНОМІКО- ЕКОЛОГІЧНОЇ БЕЗПЕКИ ДЕРЖАВИ
}

У статті розглядається економіко-екологічні проблеми енергозабезпечення України, викликаних енергозалежністю держави від імпорту паливно-енергетичних ресурсів, а також збільшенням об - 
сягу викидів шкідливих речовин у навколишнє середовище. Розглядається перспективи і переваги використання альтернативних технологій теплозабезпечення на базі технологій використання енергії навколишнього середовища.

Проаналізовано стан і динаміка відпуску теплової енергії генеруючими джерелами за останні роки. Визначено основні перешкоди та фрактори розвитку відновлюваної енергетики в Україні. Проаналізовано статистичні дані по обсягів викидів шкідливих речовин у навколишнє середовище, і їх збільшення на 8,5\% (2016 рік) в порівнянні з попереднім роком свідчить про необхідність впровадження дієвих реальних кроків щодо зменшення викидів $\mathrm{CO}_{2}$, що і вимагає заходів, необхідних для дотримання Кіотського протоколу до Рамкової конвенції ООН про кліматичні зміни.

Моральна застарілість і фрізична зношеність теплоенергетичного парку паливно-енергетичного комплексу України, висока енергозалежність, екологічна ситуація, високі економічні витрати теплозабезпечення суспільства свідчать про необхідність дієвих кроків у сфері нормативно-законодавчої бази розвитку різних видів альтернативної енергетики і стабільних привабливо-інвестиційних умов ведення бізнесу для інвесторів , що призведе до економіко-екологічної безпеки держави.

Ключові слова: енергія навколишнього середовища, економіко-екологічні проблеми, альтернативні енергозберігаючі технології, альтернативна відновлювальна енергетика.

\section{Література}

1. Касич А. О. Альтернативна енергетика: світовий та вітчизняний досвід / А. О. Касич, Я. О. Литвиненко, П. С. Мельничук // Наукові записки Національного університету «Острозька академія». Економіка. 2013. - Вип. 23. - С. 43-47.

2. Халатов А.А. Енергетика України: сучасний стан і найближчі перспективи / А. А. Халатов // Вісник Національної академії наук України. - 2016. - № 6. - С. 53-61.

3. Магійович I. Альтернативна енергетика: проблеми та перспективи розвитку / I. Магійович // Аграрна економіка. - 2012. - Т.5, № 1-2. - С. 105- 116.

4. Громова О.М. Теплонасосна енергетика в екологізації паливно-енергетичного комплексу України: перспективи розвитку та механізми управління: [монографія] / О.М. Громова, О.Л. Гетьман, Т.Д. Маркова. Одеса: ІПРЕЕД НАНУ, 2013. - 193 с.

5. Офіційний сайт Державної служби статистики України [Електронний ресурс]. - Режим доступу: http://ukrstat.gov.ua/

6. Статистичний бюлетень «Постачання та використання енергії за 2016 рік» /А.О. Фризоренко //Державна служба статистики України. - 2017. - С.23.

7. Статистичний бюлетень «Викиди забруднюючих речовин та парникових газів у атмосферне повітря від стаціонарних джерел забруднення за 2016 рік» / Прокопенко О.М. //Державна служба статистики України. 2017. - C.34.

8. Бортнюк Т. Відновлювана енергетика України / Т. Бортнюк // Економічний аналіз. - 2013. - Т. 12(1). - C. 51-54.

9. Гайдаєнко I. Альтернативна енергетика в Україні: стан та перспективи розвитку / І. Гайдаєнко // Наукові записки з української історії. - 2014. - Вип. 34. - С. 146-151.

10. Лось Л. В. Перспективна альтернативна енергетика / Л. В. Лось, М. Д. Терлецький // Вісник Житомирського національного агроекологічного університету. - 2013. - № 1(1). - С. 203-214.

Стаття надійшла 5.08.2017

Стаття прийнята до друку 19.08.2017

Доступно в мережі Internet 30.09.2017 


\section{ДЛЯ НОТАТОК}

